\title{
Structure of ocean circulation between the Galápagos Islands and Ecuador
}

\author{
C. Collins ${ }^{1}$, A. Mascarenhas ${ }^{2}$, and R. Martinez ${ }^{3}$ \\ ${ }^{1}$ Naval Postgraduate School, Monterey, CA, USA \\ ${ }^{2}$ (LAMCE-COPPE) Universidade Federal do Rio de Janeiro, Rio de Janeiro, Brazil \\ ${ }^{3}$ Centro Internacional para la Investigación del Fenómeno de El Niño, Guayaquil, Ecuador \\ Correspondence to: C. Collins (collins@nps.edu)
}

Received: 24 May 2011 - Revised: 11 September 2011 - Accepted: 1 October 2012 - Published: 2 April 2013

\begin{abstract}
From 27 March to 5 April 2009, upper ocean velocities between the Galápagos Islands and Ecuador were measured using a vessel mounted ADCP. A region of possible strong cross-hemisphere exchange was observed immediately to the east of the Galápagos, where a shallow (200 m) $300 \mathrm{~km}$ wide northeastward surface flow transported 7-11 Sv. Underlying this strong northeastward surface current, a southward flowing undercurrent was observed which was at least $600 \mathrm{~m}$ thick, $100 \mathrm{~km}$ wide, and had an observed transport of 7-8 Sv. Next to the Ecuador coast, the shallow $(<200 \mathrm{~m})$ Ecuador Coastal Current was observed to extend offshore $100 \mathrm{~km}$ with strongest flow, $0.33 \mathrm{~m} \mathrm{~s}^{-1}$, near the surface. Immediately to the west of the Ecuador Coastal Current, flow was directed eastward and southward into the beginnings of the Peru-Chile Countercurrent.

The integral of the surface currents between the Galápagos and Ecuador agreed well with observed sea level differences. Although the correlation of the sea level differences with large scale climate indices (Niño3 and the Southern Oscillation Index) was significant, more than half of the sea level variability was not explained. Seasonal variability of the sea level difference indicated that sea level was $2 \mathrm{~cm}$ higher at the Galápagos during late winter and early spring, which could be associated with the pattern of northward surface flows observed by R/V Knorr.
\end{abstract}

\section{Introduction}

From 27 March to 5 April 2009, R/V Knorr conducted scientific studies between the Galápagos Islands and Ecuador. Although the focus of the cruise was upon obtaining sediment cores, Ecuador requested that underway current measurements be collected. Few such data sets are available (Karnauskas et al., 2010). The purpose of this paper is to describe the circulation and transport patterns observed by R/V Knorr and to relate the former to sea level differences between the Galápagos and Ecuador.

The circulation has been measured directly by surface drifters (Fig. 4 in Kessler, 2006) and vessel-mounted current profilers (Karnauskas et al., 2010) and deduced using water properties and dynamic topography (Kessler, 2006; Lukas, 1986). The dynamic topography between the Galápagos and the Ecuador and northern Peru coast is dominated by a cyclonic gyre, which appears as a trough in the surface dynamic topography which extends from $13^{\circ} \mathrm{S}$ at the coast of Peru to the west-northwest, where it is located south and west of the Galápagos (Fig. 2 in Kessler, 2006). The region between $3^{\circ} \mathrm{S}$ and $5^{\circ} \mathrm{S}$ in Fig. 1 is marked by a weak gradient of dynamic height associated with eastward flow from the Galápagos toward Northern Peru along the equatorward limb of the cyclonic trough. When the eastward flow reaches the coast of South America, it is deflected southward into the Peru-Chile Countercurrent (PCCC) and the Peru Chile Undercurrent (PUC) (Fig. 15 in Lukas, 1986). The eastward flow has been attributed to a southern branch of the Equatorial Undercurrent (EUC) (Lukas, 1986; Strub et al., 1998, and others); but recent studies using numerical ocean models (Montes et al., 2010) indicate that the eastward flow into the PUC may be dominated by the Southern Subsurface Countercurrent (SSCC). (For a recent description of the SSCC see Donohue et al., 2002.) At the ocean surface, the westward movement of drifting buoys (Fig. 4 in Kessler, 2006) indicated that surface flow was dominated by Ekman transport 


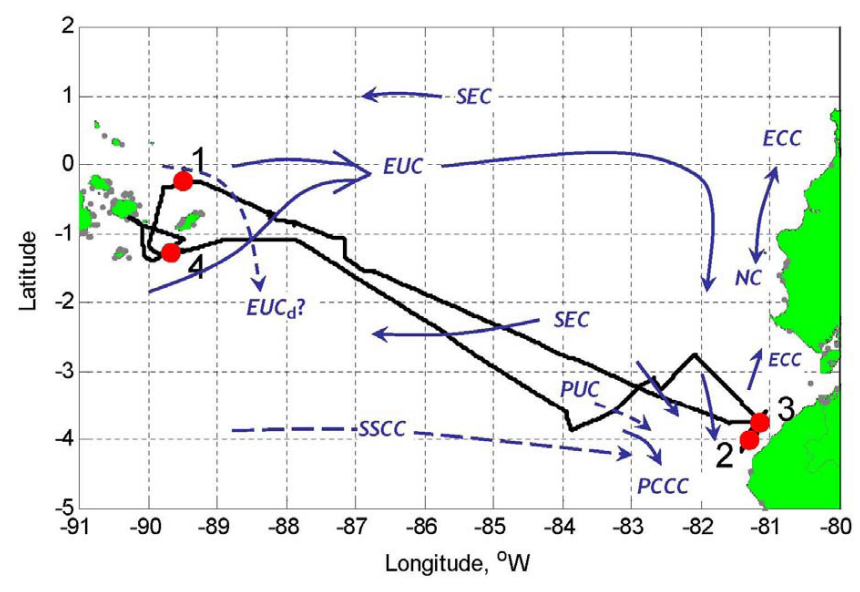

Fig. 1. Cruise track (black line) and hydrographic stations (red dots) occupied by R/V Knorr, 27 March-5 April 2009, superimposed on a schematic diagram of regional currents. Upper layer currents are solid blue lines and deeper currents are indicated by dashed blue lines. SEC is South Equatorial current, EUC is Equatorial Undercurrent, ECC is Ecuador Coastal Current, $\mathrm{NC}$ is Annual El Niño Current (present in Southern Hemisphere summer), EUC $\mathrm{d}_{\mathrm{d}}$ is the deep Equatorial Undercurrent, PCCC is the Peru Chile Countercurrent, PUC is the Peru Chile Undercurrent, and SSCC is the Southern Subsurface Countercurrent.

caused by the SE Trades. The surface drifting buoys measured weak westward flow near the South American coast which strengthened to the west, approaching $0.25 \mathrm{~m} \mathrm{~s}^{-1}$ near the Galápagos.

Studies along the Ecuador coast (Allauca, 1990) have documented a northward coastal extension of the Peru-Chile current called the Ecuador Coastal Current. The Ecuador Coastal Current appears to strengthen seasonally with trade winds, following the movement of the ITCZ and the Equatorial front. Off Northern Ecuador, the coastal flow reverses in the Southern Hemisphere summer and flows southward as the annual El Niño Current (Strub et al., 1998). A northern branch of the EUC flows along the equator from the Galápagos to Ecuador and then turns southward (offshore from the coastal flows described above), possibly feeding either the PUC or the Peru Chile Counter Current (PCCC) (Strub et al., 1998). Note that the numerical study of Montes et al. (2010), indicates that most of the flow in the northern branch of the EUC moves northward to the north of the Galápagos and thence to the west in the northern branch of the South Equatorial Current (SEC). In the region of the Galápagos, the circulation is dominated by surfacing of the undercurrent along their western boundary and upwelling events (Steger et al., 1998; Lucero and Cornejo Rodriguez, 1990; Lucero, 2000; Karnauskas et al., 2010).
During El Niño, the southern front is displaced southward and intensifies so that eastward flow along the front is strengthened. At the coast, southward advection of fresher and warmer surface waters by the Annual El Niño current is strengthened during El Niño periods (Chavez, 1986; Zambrano et al., 2000).

A schematic diagram of the currents between the Galápagos and the South American coast based upon the description above and the results described below is shown in Fig. 1. The location of the SSCC shown in Fig. 1 is as described by Montes et al. (2010), somewhat north of the $6-7.5^{\circ} \mathrm{S}, 88.8^{\circ} \mathrm{W}$ location observed by Tsuchiya and Talley (1998).

\section{Methods}

Data used in this study included underway meteorological data, sea surface temperature and salinity, shipboard measurements of ocean currents, profiles of water properties collected by CTD, sea level data from Santa Cruz (Galápagos Islands) and La Libertad (Ecuador) and climate indices. Ocean currents were measured using two vessel mounted acoustic Doppler current profilers (ADCP), a $75 \mathrm{kHz}$ "Ocean Surveyor" and a $150 \mathrm{kHz}$ narrow band instrument. The $75 \mathrm{kHz}$ instrument collected both high resolution (broadband) and long-range (narrow band) data. The $150 \mathrm{kHz}$ and $75 \mathrm{kHz}$ instruments sampled continuously at $2 \mathrm{~s}$ and $3 \mathrm{~s}$ intervals, respectively, and data were averaged into 5-min ensembles. The five-minute ensembles were processed in near real time using software developed by the University of Hawaii. The $150 \mathrm{kHz}$ and $75 \mathrm{kHz}$ broad band data used $8 \mathrm{~m}$ vertical bins and the $75 \mathrm{kHz}$ narrow band used $16 \mathrm{~m}$ bins. The current measurements extended to a maximum depth of $800 \mathrm{~m}$ for the $75 \mathrm{kHz}$ long range data and to $250 \mathrm{~m}$ for the $150 \mathrm{kHz}$ narrow band data. Transports $\left(V_{\mathrm{r}}\right)$ were estimated by rotating the currents to flow in the direction of the mean current, $v_{\mathrm{r}}$, so $V_{\mathrm{r}}=\iint v_{\mathrm{r}} \mathrm{d} x \mathrm{~d} z$, where $z$ is depth, $x$ the distance from the current axis, and the limits of integration determined by the zero isotach.

A Seabird 911plus CTD was used. CTD sensors were calibrated in mid-March 2008. There were no bottle samples available to adjust CTD measured salinities. Steric height, $h^{\prime}$, was determined from CTD soundings as $h^{\prime}=g^{-1} \int \alpha \mathrm{d} p$ where $g$ is gravity, $\alpha$ is specific volume anomaly, and $p$ is pressure (Talley et al., 2011).

Daily sea level data were downloaded from the University of Hawaii Sea Level Center. For 2008 and 2009, hourly sea level data were used. Hourly data for La Libertad (Santa Cruz) were provided by the Ecuador Navy (University of Hawaii Sea Level Center). Climate indices (Southern Oscillation Index, Niño3) were obtained from the Climate Prediction Center (http://www.cpc.ncep.noaa.gov/data/indices). 


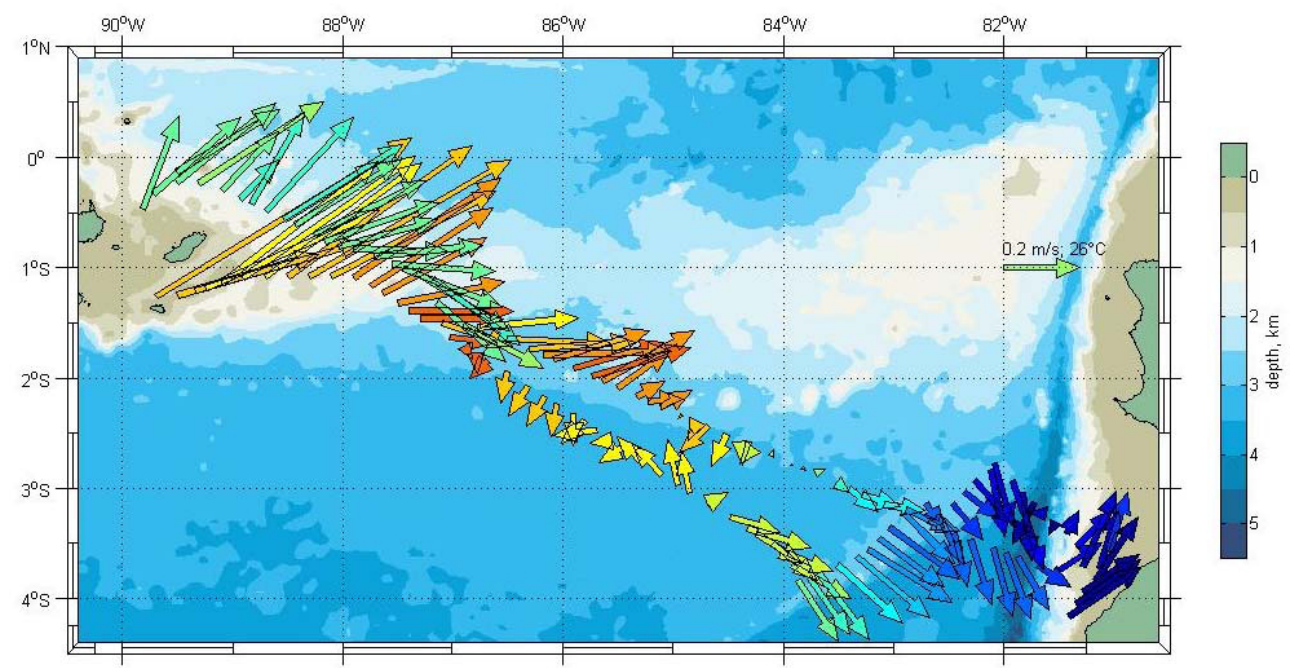

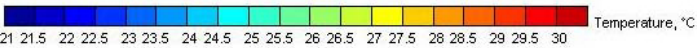

Fig. 2. Currents at $50 \mathrm{~m}$. The color of the arrows corresponds to $5 \mathrm{~m}$ temperature. The vertical bar at the right is the scale used for ocean depth. Data were binned into $0.2^{\circ}$ longitude by $0.1^{\circ}$ latitude bins.

\section{Results}

The ship track is shown in Fig. 1. The ship departed Puerto Ayora, Galápagos Islands, on 27 March 2009, proceeding to the area near the first CTD station. Completing work at this location, the ship moved eastward, occupying the most southern CTD station (designated \#2 on Fig. 1) near the Peru coast about four days later on 31 March. A day later, on 1 April, station 3 was occupied. The ship zigzagged to the northeast and southwest off the Gulf of Guayaquil before returning to the Galápagos, arriving at the fourth and final CTD station on 4 April.

\subsection{Currents}

All three ADCP measurements yielded similar current patterns. The $75 \mathrm{kHz}$ broad band data were used in Figs. 2 and 3 because they resolved currents in $8 \mathrm{~m}$ bins vice $16 \mathrm{~m}$ for the $75 \mathrm{kHz}$ narrow band. Near surface $(50 \mathrm{~m})$ currents are shown in Fig. 2, and flow at $200 \mathrm{~m}$ is shown in Fig. 3. Strongest flow patterns occurred at the eastern and western boundaries. Near the Galápagos Islands, the surface flow was strong $\left(>0.5 \mathrm{~m} \mathrm{~s}^{-1}\right)$ and directed toward the northeast (Fig. 2). Immediately beneath the westward half of the northward surface flow, a southeastward-directed undercurrent occurred (Fig. 3), which extended from about $100 \mathrm{~m}$ to $700 \mathrm{~m}$ (the limit of the ADCP range) with peak speeds of 0.2 to $0.4 \mathrm{~m} \mathrm{~s}^{-1}$. At $200 \mathrm{~m}$, between $88^{\circ} \mathrm{W}$ and $87^{\circ} \mathrm{W}$, the southeastward undercurrent disappeared and the northeastwardflowing surface current deepened, although its magnitude was somewhat reduced.
East of $87^{\circ} \mathrm{W}$, the $50 \mathrm{~m}$ flow was eastward between $1^{\circ} \mathrm{S}$ and $2^{\circ} \mathrm{S}$. For the northward track, the eastward flow continued to $85^{\circ} \mathrm{W}$, whereas weak south and westward flow was observed at $50 \mathrm{~m}$ on the southward track between $86-85^{\circ} \mathrm{W}$ (Fig. 2). Between $85^{\circ} \mathrm{W}$ and $84^{\circ} \mathrm{W}$, the $50 \mathrm{~m}$ currents were weak and variable. East of $84^{\circ} \mathrm{W}$ and south of $3^{\circ} \mathrm{S}$, the eastward $50 \mathrm{~m}$ flow strengthened to 0.2 to $0.3 \mathrm{~m} \mathrm{~s}^{-1}$ and veered southward at $82^{\circ} \mathrm{W}$. This is flow of surfaced Equatorial Undercurrent waters into the Peru Chile Countercurrent as described by Lukas (1986). The flow is relatively shallow, as at $200 \mathrm{~m}$ (Fig. 3) its speed is reduced to about $0.1 \mathrm{~m} \mathrm{~s}^{-1}$ and it seemed to be displaced southward, appearing only to the south of $3.6^{\circ} \mathrm{S}$.

Over the continental slope to the west of the Gulf of Guayaquil, the Ecuador Coastal Current was well defined at $50 \mathrm{~m}$ (Fig. 2) as a north-northeastward flow into the Gulf at a rate of about $0.25 \mathrm{~m} \mathrm{~s}^{-1}$. This too was a shallow flow, and at $200 \mathrm{~m}$ (Fig. 3) the currents underneath the Ecuador Coastal Current were weak with variable direction. The $200 \mathrm{~m}$ flow in this region was much weaker $\left(<0.05 \mathrm{~m} \mathrm{~s}^{-1}\right)$, although a band of somewhat stronger ( 0.1 to $0.2 \mathrm{~m} \mathrm{~s}^{-1}$ ) eastward flow occurred south of $3^{\circ} \mathrm{S}$ between $84^{\circ} \mathrm{W}$ and $83^{\circ} \mathrm{W}$.

At $200 \mathrm{~m}$, westward flow in the South Equatorial Current was restricted to the area between $2^{\circ} \mathrm{S}$ and $3^{\circ} \mathrm{S}$ (Fig. 3).

Examples of the vertical structure of the surface boundary currents described above are shown in Fig. 4. The eastward transit was used to depict the currents next to the Peru and Ecuador coasts and the westward transit for the northeastward flow next to the Galápagos. Since the structure of the flow next to the coast of the Galápagos was similar on both 

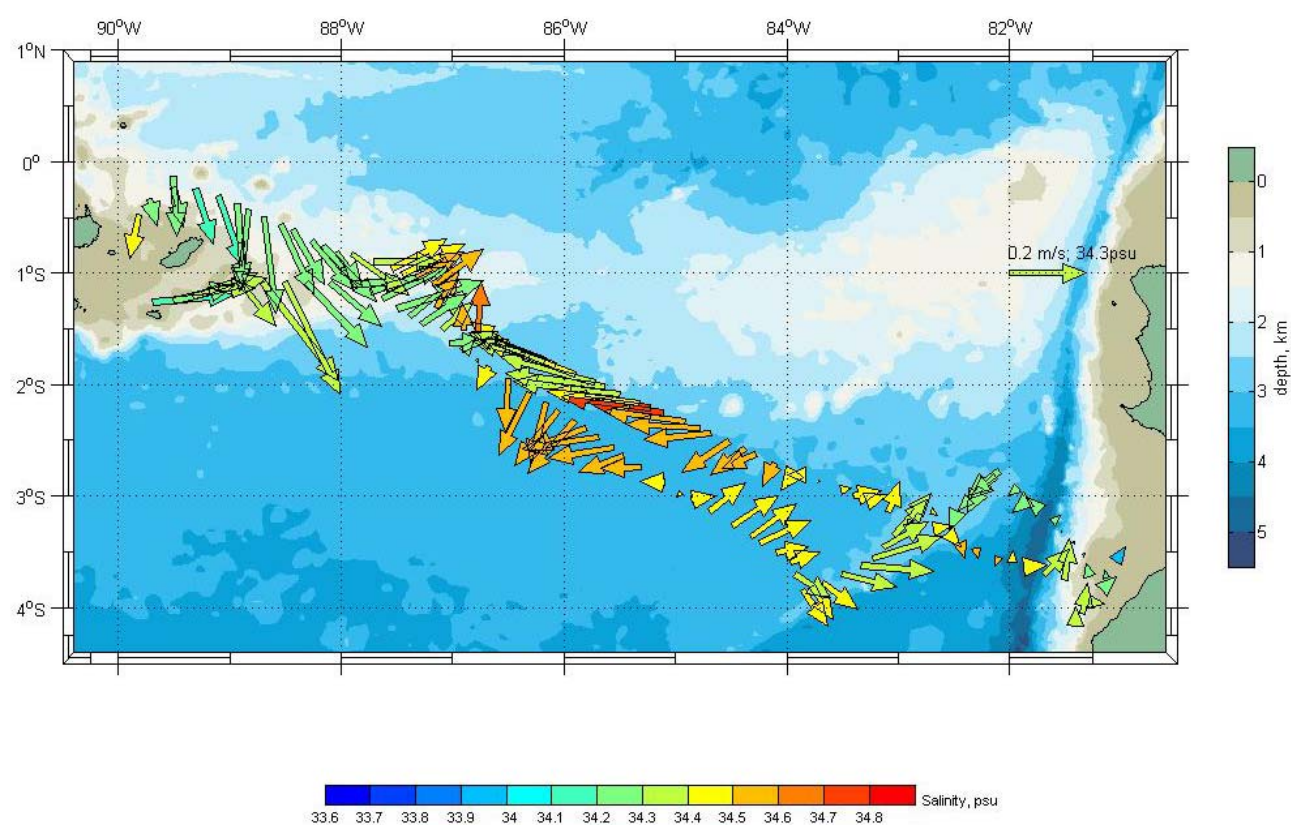

Fig. 3. Currents at $200 \mathrm{~m}$. The color of the arrows corresponds to the $5 \mathrm{~m}$ salinity. The vertical bar at the right is the scale used for ocean depth. Data were binned into $0.2^{\circ}$ longitude by $0.1^{\circ}$ latitude bins.
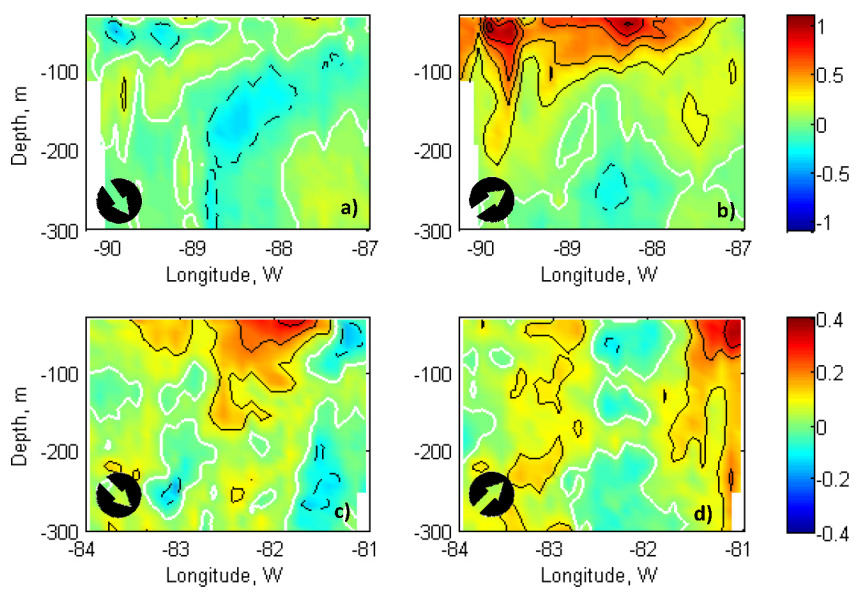

Fig. 4. Upper Ocean Boundary Currents. Data have been averaged by $0.1^{\circ}$ longitude bins. The color bars to the right indicate the different velocity scales used for the upper and lower panels. Positive velocities are solid black lines which enclose yellow to red colors, negative velocities are dashed black lines which enclose blue colors, and the zero isotach is white. The direction of the flow depicted in each panel is indicated by an arrow in the lower left corner. Coastal flow eastward of the Galápagos, 3-5 April 2009, is shown in (a) for across stream flow (directed toward $145^{\circ} \mathrm{T}$ ) and in (b) for along stream flow (directed toward $55^{\circ} \mathrm{T}$ ) using a contour interval $0.2 \mathrm{~m} \mathrm{~s}^{-1}$. Ecuador Coastal Currents for the period 29-30 March 2009 are shown in (c) for across-shore flow (directed toward $135^{\circ} \mathrm{T}$ ) and in (d) for alongshore flow (directed toward $045^{\circ} \mathrm{T}$ ) using a contour interval $0.1 \mathrm{~m} \mathrm{~s}^{-1}$. transits, it was assumed that the variation of the flow in the direction of the current was less than its variation across the current. The northeastward-flowing surface current next to the Galápagos is shown in Fig. 4a, b. The currents were rotated so that the component of flow in the direction of the current is $55^{\circ} \mathrm{T}$ (Fig. 4b) and the across stream flow $145^{\circ} \mathrm{T}$ (Fig. 4a). The core of the flow $\left(>0.2 \mathrm{~m} \mathrm{~s}^{-1}\right)$ appeared as a wedge which extended to a depth of $200 \mathrm{~m}$ next to the coast and shoaled to the surface at $87.2^{\circ} \mathrm{W}$. Strongest flow was near the surface, $1.1 \mathrm{~m} \mathrm{~s}^{-1}$ ( $2 \mathrm{kts}$ ). The weakening of the flow near $89.6^{\circ} \mathrm{W}$ was likely due to the upstream proximity of Española Island. The mean speed of the northeastward flow shown in the upper right panel of Fig. 4 was $0.38 \mathrm{~m} \mathrm{~s}^{-1}$ and the transport was 11.4 Sv. The section across this current to the immediate north indicated a mean speed of $0.27 \mathrm{~m} \mathrm{~s}^{-1}$, a direction of $48^{\circ} \mathrm{T}$, and a transport of $6.6 \mathrm{~Sv}$.

The surface flow at the Ecuador coast is shown in Fig. 4c, d. The flow for the coastal section was rotated so that the flow observed closest to the coast was parallel to the coastline and directed to the northeast. The northeastwardflowing Ecuador Coastal Current (ECC) is shown in Fig. 4d to the east of $82^{\circ} \mathrm{W}$. Strongest flow, $0.33 \mathrm{~m} \mathrm{~s}^{-1}$, was next to the coast at $50 \mathrm{~m}$ depth. Immediately to the west of the Ecuador Coastal Current, a core of shallow southeastward flow ( $>0.2 \mathrm{~m} \mathrm{~s}^{-1}$ above $170 \mathrm{~m}$ ) was observed between $82-$ $83^{\circ} \mathrm{W}$ with strongest velocities near the surface (Fig. 4c). This flow appeared to feed the southward-flowing Peru-Chile countercurrent. Estimates for the rate of mean flow and transport for these surface flows near the Ecuador coast were not 

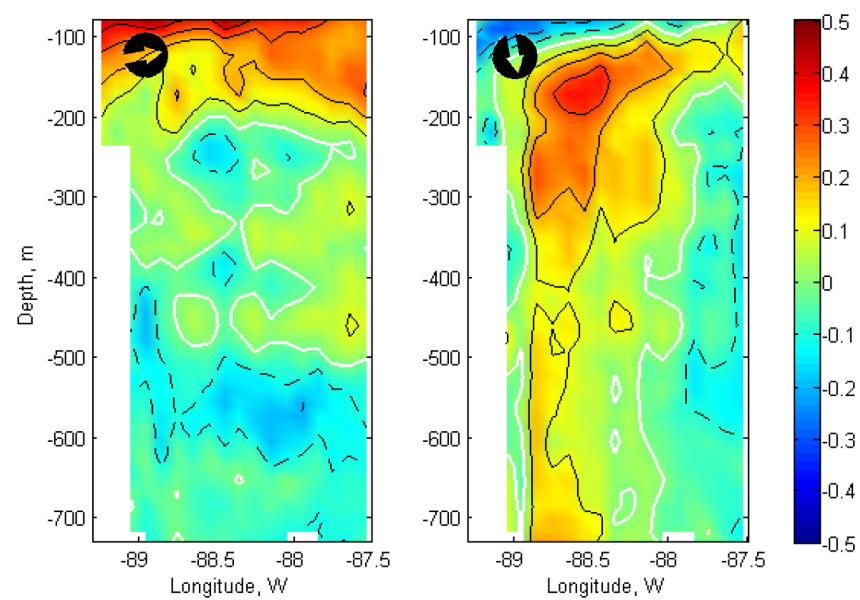

Fig. 5. Undercurrent to the east of the Galápagos, 3-5 April 2009. Data have been averaged by $0.1^{\circ}$ longitude bins. The color bar to the right indicates the velocity scale used for both panels. Positive velocities are solid black lines which enclose yellow to red colors, negative velocities are dashed black lines which enclose blue colors, and the zero isotach is white. Contour interval is $0.1 \mathrm{~m} \mathrm{~s}^{-1}$. The direction of the flow depicted in each panel is shown by the arrow in the upper left corner. (Left panel) Cross stream (toward $080^{\circ} \mathrm{T}$ ) flow. (Right panel) Alongstream flow (toward $170^{\circ} \mathrm{T}$ ).

possible, as the ship did not manage to reach the eastern or southern boundaries of the flows.

The structure of the deep undercurrent next to the Galápagos is shown in Fig. 5 for the westward (southern) transit. The right panel shows the flow directed along the undercurrent in the direction $170^{\circ} \mathrm{T}$. The undercurrent was about $100 \mathrm{~km}$ in width and extended from a depth of $100 \mathrm{~m}$ to the deepest levels observed, greater than $700 \mathrm{~m}$. A core of strong $\left(>0.3 \mathrm{~m} \mathrm{~s}^{-1}\right)$ flow was observed at a depth of $170 \mathrm{~m}$ at $88.5^{\circ} \mathrm{W}$. The mean speed of the undercurrent shown in Fig. 5 was $0.10 \mathrm{~m} \mathrm{~s}^{-1}$, with transport of $8.2 \mathrm{~Sv}$. The undercurrent observed on the eastward (northern) transit had a mean speed of $0.11 \mathrm{~m} \mathrm{~s}^{-1}$, flowed south-southwestward $\left(219^{\circ} \mathrm{T}\right)$, and had a transport of $6.7 \mathrm{~Sv}$.

\subsection{Hydrography}

Near surface $(5 \mathrm{~m})$ temperature (salinity) is shown in Fig. 2 (3). Warmest near surface waters, $28-29^{\circ} \mathrm{C}$, occurred between $1-2^{\circ} \mathrm{S}$ and coolest waters, $21-24^{\circ} \mathrm{C}$, near the South American coast (Fig. 2). The largest near surface salinity gradient occurred between the two CTD stations off Ecuador, where surface salinity was 34.28 at station 3 and 34.72 at station 2 (Fig. 3). The stations were only $31.6 \mathrm{~km}$ apart.

A high resolution $(37 \mathrm{~km}$ CTD profiles) section along $85^{\circ} 50^{\prime} \mathrm{W}$ was occupied in late March 1993 by R/V Knorr (Tsuchiya and Talley, 1998). The surface temperature conditions that were observed between $1-2^{\circ} \mathrm{S}$ on the 1993 cruise were similar to those described above: between the Equator and $5^{\circ} \mathrm{S}$, maximum sea surface temperatures were $29^{\circ} \mathrm{C}$ at about $2^{\circ} \mathrm{S}$. But sea surface salinities in 1993 at $1-2^{\circ} \mathrm{S}$ were $\mathrm{S} \approx 33.5$, indicating the presence of equatorial surface water (Tsuchiya and Talley, 1998).

Water properties obtained from CTD soundings are shown in Fig. 6. Three water properties indicated the presence of the Equatorial Undercurrent: a shallow subsurface salinity maximum, a thermostad near $13^{\circ} \mathrm{C}$ (Fig. 6, upper left), and enhanced oxygen at $100 \mathrm{~m}$ (Lukas, 1986). The salinity maximum occurred at a depth of about $75 \mathrm{~m}$ (Fig. 6, upper right). To the east of the Galápagos Islands (CTD stations 1 and 4), the maximum subsurface salinity exceeded 35.1 , while next to the South American coast (CTD stations 2 and 3) the salinity maximum was about 35 . These salinities are slightly higher $(\sim 0.1)$ than those reported by Lukas (1986). The density profiles (not shown) yielded a Rossby internal radius of deformation that varied from $200 \mathrm{~km}$ (station 2) to $4000 \mathrm{~km}$ (station 1).

The thicknesses of the thermostads were estimated by the depth difference between the 180 and $160 \mathrm{cL} \mathrm{t}^{-1}$ specific volume anomaly surfaces (Lukas, 1986). Stations 1 and 4 (2 and 3) had thicknesses of 139 and $100 \mathrm{~m}$ ( 89 and $84 \mathrm{~m}$ ), respectively. These values also agree well with mean values given in Fig. 4 in Lukas (1986), although the thermostad thicknesses found along the coast of South America were somewhat greater than the March-April mean, $72 \mathrm{~m}$ (Table 2 in Lukas, 1986).

Dissolved oxygen profiles are shown in Fig. 6, lower right. Values observed at $100 \mathrm{~m}$ were $2.0 \mathrm{mLL}^{-1}$ and $2.3 \mathrm{mLL}^{-1}$ $\left(1.4 \mathrm{~mL} \mathrm{~L}^{-1}\right.$ and $\left.1.2 \mathrm{mLL}^{-1}\right)$ for stations 1 and 4 (2 and 3), respectively. These oxygen concentrations were slightly less than the mean values at $100 \mathrm{~m}$ reported by Lukas (1986) except for station 4 , which was larger by $0.2 \mathrm{mLL}^{-1}$.

\subsection{Ocean transport profile}

Figure 7 compares the geostrophic transport derived from the horizontal pressure gradients obtained from the CTD casts with those that were directly measured by shipboard ADCP. The shipboard currents were binned into $0.2^{\circ}$ longitude bins for the transits between CTD stations 1 and 2 and stations 3 and 4 , rotated into a coordinate frame which yielded the velocity component perpendicular to the CTD transit, and then integrated horizontally. In the following paragraph, these rotated transports will be referred to as "northward" or "southward" even though the northward- (southward-) directed component had a small eastward (westward) component as well.

For the CTD derived transports, the deepest common depth for the CTD pairs was used as the reference level, e.g. the level of no motion. These geostrophic estimates can be adjusted to a level of known motion which is chosen as a level where the directly observed currents changed little with depth. Between 200 and $300 \mathrm{~m}$, the observed current transport was relatively stable, about $-0.2 \mathrm{~m}^{3} \mathrm{~s}^{-1}$. Assigning this value to the geostrophic transports at these depths yielded a 

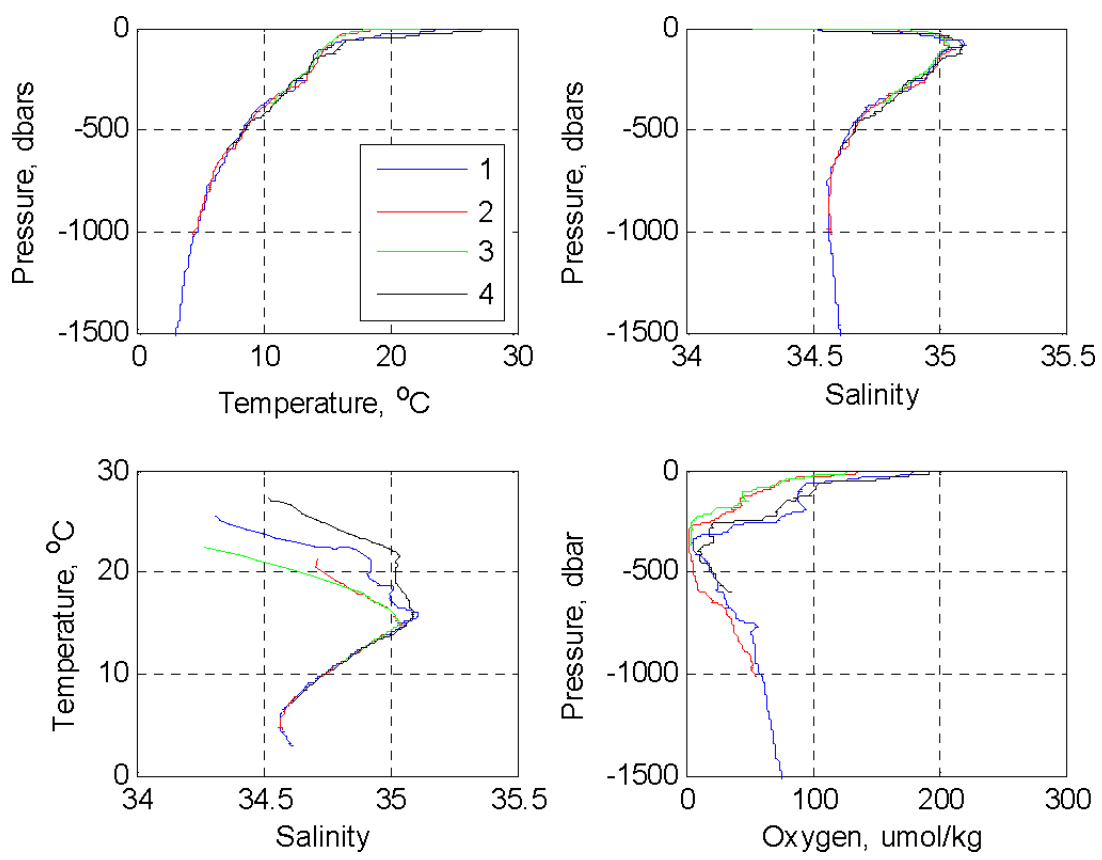

Fig. 6. CTD measurements at stations shown in Fig. 1. (Upper left) Temperature versus pressure. The legend in the lower right of this figure identifies individual stations by color and is used in the other three panels. (Upper right) Salinity versus pressure. (Lower right) Dissolved oxygen versus pressure. (Lower left) Temperature versus salinity.

similar pattern to that of the observed transports for the variation of transport with depth above $300 \mathrm{~m}$, e.g. northward at the surface and southward at $200 \mathrm{~m}$. A major difference is that the reversal of the transport observed by ADCP was 50$100 \mathrm{~m}$ deeper than that of the adjusted geostrophic transport.

The difference in the transport profile measured by ADCP on the two transits was greatest at a depth of about $400 \mathrm{~m}$, where the transport measured between stations 1 and 2 was $-0.7 \mathrm{~m}^{3} \mathrm{~s}^{-1}$ while that between stations 3 and 4 was $0.2 \mathrm{~m}^{3} \mathrm{~s}^{-1}$. This difference was related to changes in the direction of the currents at $400 \mathrm{~m}$ from northward across the eastbound section between $86^{\circ} \mathrm{W}$ to $84^{\circ} \mathrm{W}$ to southward over the same region on the westbound section. Chaigneau et al. (2008) studied mesoscale eddies off Peru using sea surface height anomalies determined by satellite altimetry. Their study region extended northward to $3^{\circ} \mathrm{S}$, where they observed eddies about $20 \%$ of the time with eddy kinetic energies of $0.02 \mathrm{~m}^{2} \mathrm{~s}^{-2}$ and $150 \mathrm{~km}$ radius. AVISO SSHA fields (Collecte Localisation Satellites, 2006) were checked to see if there were mesoscale eddies in the region between the Galápagos and South America in late March and early April of 2009: none existed. So the current perturbation at $400 \mathrm{~m}$ may be either too deep or too weak to be seen at the surface or may not be in geostrophic balance.

\subsection{Sea level differences and ocean transports}

Changes in regional circulation patterns are associated with changes in steric height and sea level. Wyrtki (1978) used sea level data to describe the temporal variation of transport by equatorial ocean currents, as did Hayes (1985) for the Galápagos Islands. Sea level has been routinely measured at Santa Cruz and Baltra Islands in the Galápagos and at La Libertad, Ecuador, as part of the Global Sea Level Observing System (GLOSS). These sea level data show a dramatic response to El Niño conditions, when sea level can increase by as much as $0.4 \mathrm{~m}$ (Hayes et al., 1986). Can differences of sea level between the Galápagos and Ecuador be used to either describe changes in ocean circulation or forecast coastal ocean conditions?

Figure 8 shows the variation of sea level differences observed between Santa Cruz Island and La Libertad for the period of the R/V Knorr cruise. Here hourly data were used and smoothed to remove frequencies greater than 0.5 per day. The higher sea level observed at Santa Cruz implied a mean northward surface flow between the Galápagos Islands and Ecuador.

Sea level differences can also be calculated from the differences in steric height determined from hydrographic data referenced to a level of no motion or by determining the sea level difference that would geostrophically balance the observed average surface current between two locations. These estimates are also shown in Fig. 8. Since good agreement was obtained for the magnitude and trend of the sea level differences observed by tide gauges and those needed to balance the surface currents, it is useful to determine if tide gauge data can be used as a regional circulation index. 


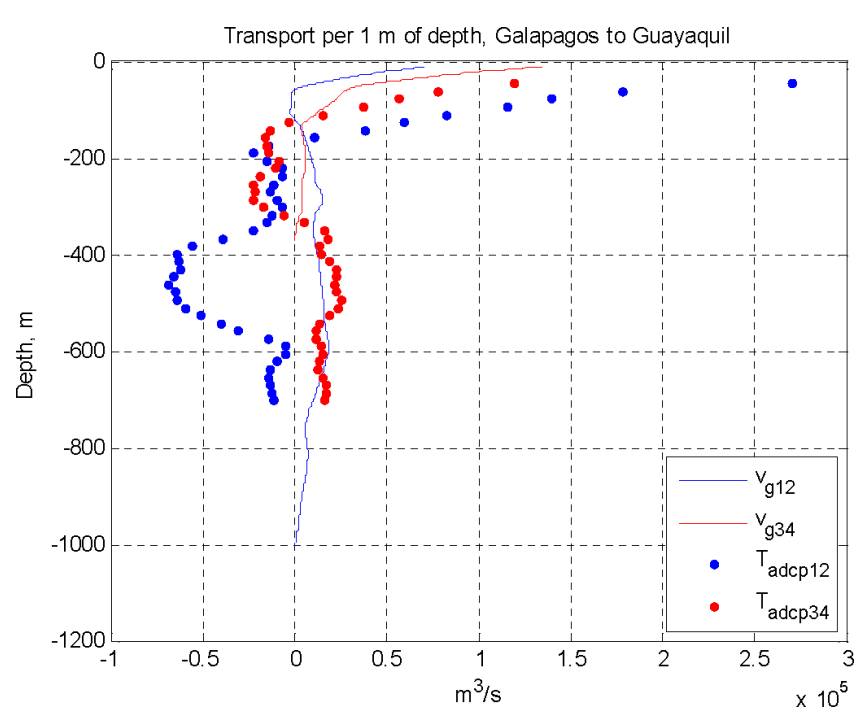

Fig. 7. Transport per $1 \mathrm{~m}$ of depth. Lines indicate geostrophic transports using the deepest common depth between the indicated CTD stations. Dotted lines are transports obtained by integrating the component of the directly observed current which is perpendicular to the line that connects the two CTD stations. Blue is used for stations 1 and 2 and red for stations 3 and 4 .

Daily sea level observations for the period 1978 to 2008 were readily available for both Santa Cruz and La Libertad tide gauge data. A plot of daily sea level for the two locations (not shown) shows systematic drift at La Libertad between 1980 and 1990 and again from 1998 to 2008, about $0.2 \mathrm{~m}$ for each decade. This rate of sea level rise is unrealistic - for example current estimates of global sea level rise are $3 \mathrm{~mm} \mathrm{yr}^{-1}$ (Church and White, 2006). So the drift is more likely due to slow sinking of the tide gauge or errors in datum measurements. The drift in the La Libertad data was removed by fitting a sixth-degree polynomial to the daily sea level time series. Then the data were smoothed to eliminate frequencies greater than 0.5 per month (but not semiannual and longer variability). The upper panel of Fig. 9 shows the resulting time series of the detrended and smoothed difference of sea level between the Galápagos and Ecuador. Positive values occurred during strong El Niño periods (19821983, 1997-1998), but largest values were at other times (1990 and 2001). The sea level differences were correlated with the Nino3 (SOI) index with $r=0.55$ (0.40), but less than half the variability could be reproduced with a linear fit. Clearly, regional as well as large scale variability was reflected in the sea level difference time series, and further analysis using regional indices is needed (see Martinez et al., 2000, 2002).

Another way to eliminate the unrealistic long term trends $(0.2 \mathrm{~m}$ per decade) at La Libertad is to bin the data for a frequency which is short relative to the record length. This was done for the annual cycle, and the mean is shown in the lower panel of Fig. 9 for Santa Cruz and La Libertad. The pattern of

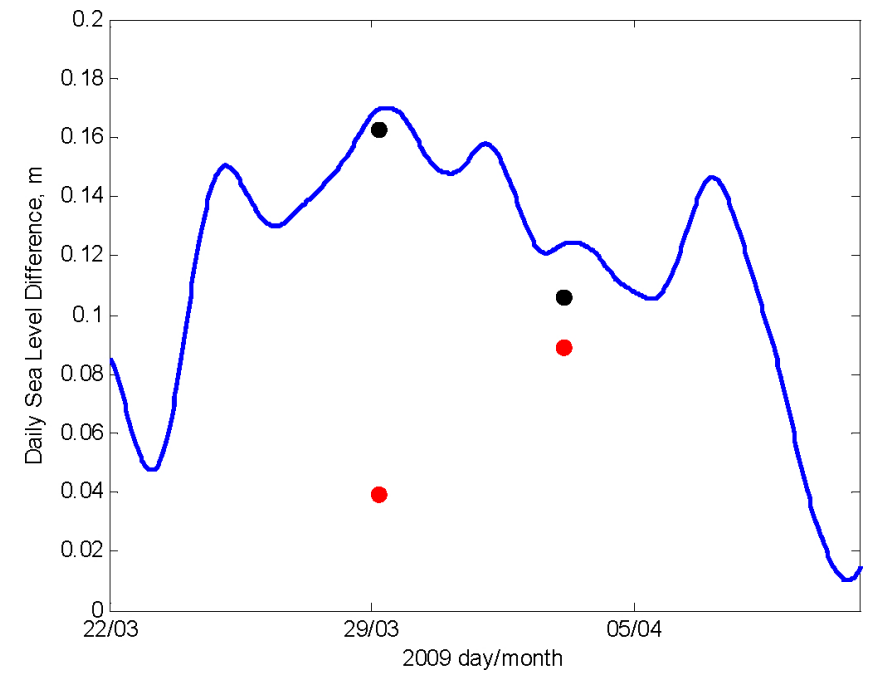

Fig. 8. Sea Level Differences, Santa Cruz minus La Libertad, 22 March to 11 April 2009. The blue line is the difference in sea level as measured by tide gauges at Santa Cruz and La Libertad. The red dots represent the steric height differences between CTD station pairs and the black dots represent the sea level difference required to geostrophically balance the mean velocity in the upper layers as measured by the acoustic Doppler current profiler.

annual sea level variability at the two locations was similar, with an amplitude of about $5 \mathrm{~cm}$ and maximum sea level near day 140 (20 May) and minimum near day 250 (7 September). The standard error of the daily mean sea level ranged from 1 to $2 \mathrm{~cm}$.

This annual pattern of sea level variability shown for tide gauges in Fig. 9 (lower) can be compared to the annual variability of steric heights determined from ocean climatology. The CTD data shown in Fig. 6 were compared with data obtained from the CSIRO Atlas of Regional Seas for 1 April (CARS, http://www.marine.csiro.au/ dunn/cars2009/). The profiles obtained from the climatology near the Galápagos were similar, but the two CARS stations near South America were about $\Delta \mathrm{S}=0.4$ too fresh and $3-5^{\circ} \mathrm{C}$ too warm in the upper layer (not shown). The steric heights which were retrieved from CARS for the location of stations 1 and 4 near the Galapagos ranged from $1.40 \mathrm{~m}$ in June to $1.32 \mathrm{~m}$ in September and October, about the same height difference and timing as shown for the Santa Cruz tide gauge (Fig. 9, lower). Near the South American coast, the maximum steric height, $1.4 \mathrm{~m}$, occurred much earlier in January, while the minimum, $1.34 \mathrm{~m}$, occurred at the same time as the tide gauge measurements in September (lower). A more detailed investigation of these differences between observations and climatology is beyond the scope of this paper. But it is interesting to speculate that differences observed in upper ocean water properties might be due to increased upwelling and equatorward transport along South America. 

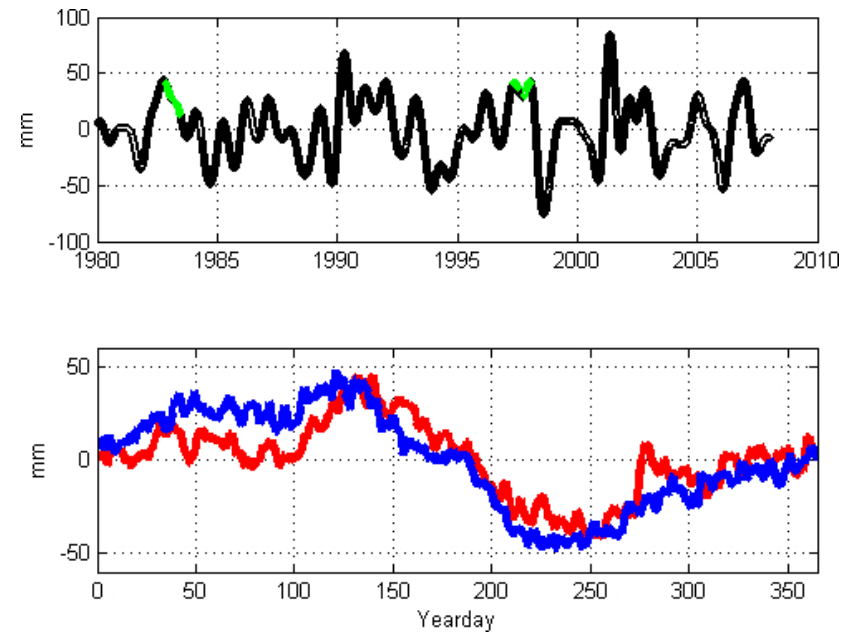

Fig. 9. Sea level variability measured by tide gauges at Santa Cruz and La Libertad. (Upper panel) Sea level difference, Santa Cruz minus La Libertad, 1978 through 2008. The mean has been removed and data have been smoothed so frequencies below one cycle per month are suppressed. Green indicates periods of maximum sea level elevation (El Niño) at Santa Cruz. White dots indicate periods when there are no tide gauge data available for either Santa Cruz or La Libertad. (Lower panel) Seasonal sea level cycle for Santa Cruz (blue) and La Libertad (red).

The CARS climatology was also used to compute the annual variability of the geostrophic transport referenced to 1000 dbar between the Galapagos and South America. Maximum transport, 7.3 Sv, occurred in March and minimum, $-6.9 \mathrm{~Sv}$, in June. The geostrophic transport observed between stations 1 and 2 (Fig. 1) in late March 2009, was 10.0 Sv. This too confirms the good agreement between the R/V Knorr CTD observations and climatology.

The largest difference in annual variability of sea level between Santa Cruz and La Libertad occurred between day 50 and 100, when sea level at Santa Cruz appeared as much as $2 \mathrm{~cm}$ higher than at La Libertad (Fig. 9, lower). While this difference is close to the standard error, it persisted for about 50 days and is significant. It corresponds to an increase of the average northward flow between the Galápagos and South America of $0.04 \mathrm{~m} \mathrm{~s}^{-1}$. An example of seasonal northward flows at about this time (yearday 100) included the strong northward flow of the surfaced EUC flow to the east of the Galápagos and the northward flowing EEC along the South American coast shown in Fig. 2.

\section{Summary}

As mentioned in the introduction, the path of Equatorial Undercurrent waters around and through the Galápagos is poorly observed. Knauss (1966), Stevenson and Taft (1971), and Pak and Zaneveld (1973) observed evidence of Equatorial Undercurrent waters flowing northward around the
Galápagos and Lukas (1986) traces this path along the equator toward South America as a tongue of enhanced dissolved oxygen at $100 \mathrm{~m}$. A more recent set of vessel mounted current measurements is described by Karnauskas et al. (2010), and they conclude that it is the deeper portion of the EUC that circulates eastward to the north of the Islands and that the shallow portion of the EUC circulates eastward to the south. The current observations reported above for the 2009 R/V Knorr cruise showed a shallow $(200 \mathrm{~m}), 300 \mathrm{~km}$ wide northeastward surface flow immediately to the east of the Galápagos. Subsurface salinity maxima, thermostad thicknesses, and dissolved oxygen at $100 \mathrm{~m}$ identified these waters as originating in the Equatorial Undercurrent. The observed transport, 7-11 Sv, agreed well with the $6.6 \mathrm{~Sv}$ of transport of the Equatorial Undercurrent to the west of the Galápagos $\left(92^{\circ} \mathrm{W}\right)$ reported by Steger et al. (1998).

A southward flowing undercurrent was observed to lie under the northeastward surface current over the slope to the east of the Galápagos. This Galápagos undercurrent was at least $600 \mathrm{~m}$ thick, $100 \mathrm{~km}$ wide, and had an observed transport of 7-8 Sv. This feature of the circulation has not been previously reported; but it is interesting to speculate that this is the northern branch of the EUC as described by Karnauskas et al. (2010). It can transport waters across the equator and must interact dynamically with the overflowing waters as well. Since it is a deeper current, it may contribute to the PUC.

Next to the Ecuador coast, the shallow $(<200 \mathrm{~m})$ Ecuador Coastal Current was observed to extend offshore $100 \mathrm{~km}$ with strongest flow, $0.33 \mathrm{~m} \mathrm{~s}^{-1}$, near the surface. Immediately to the west of the Ecuador Coastal Current, flow was directed eastward and southward into the beginnings of the PeruChile countercurrent.

The integral of the surface currents between the Galápagos and Ecuador agreed well with the observed sea level differences. Although the correlation of the sea level differences with large scale climate indices (Niño3 and the Southern Oscillation Index) was significant, a large amount of the sea level variability was not explained. Further study might be able to link the unexplained variability of the sea level differences to regional processes. The seasonal variability of the sea level difference indicated that sea level was $2 \mathrm{~cm}$ higher at the Galápagos during late winter and early spring, which should contribute to a seasonal pattern of eastward and northward acceleration of regional surface circulation and might be associated with northward surface flow of Equatorial Undercurrent waters just to the east of the Galápagos Islands reported here.

Finally, a discrepancy between the current patterns derived from observations and numerical ocean models is noted, specifically whether the EUC or the SSCC provide source waters for poleward flows along Peru and Chile.

Although acoustic Doppler current profilers were developed to aid vessel navigation and piloting-they are used for dead reckoning on US Navy minesweepers - current practice 


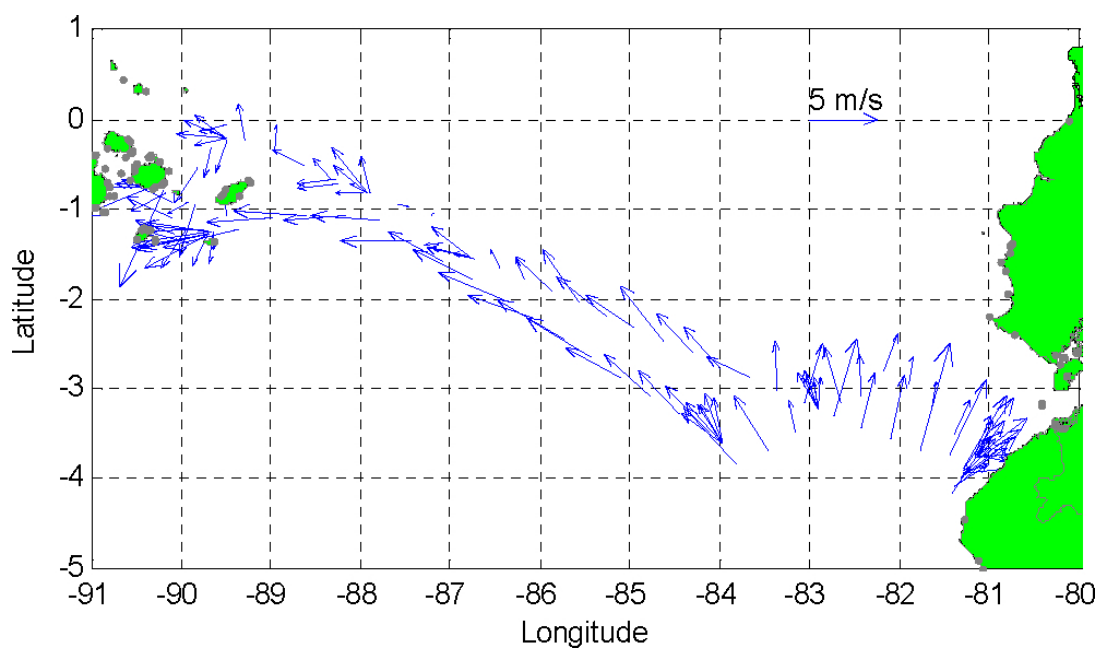

Figure A1. Observed winds, 27 March-5 April 2009.

amongst the US academic research fleet is to secure the ADCPs while transiting the Exclusive Economic Zones of foreign countries. This practice has resulted in a number of climatologically important regions (such as the Eastern Tropical Pacific or the Northwest Indian Ocean) having relatively few observations of deep-sea current patterns. This is similar to not allowing measurements of winds, air temperatures, and humidity, and has a negative impact on maritime safety.

\section{Appendix A}

\section{Near surface wind patterns}

Figure A1 shows the winds observed by R/V Knorr. Surface winds at low latitudes are difficult to determine from synoptic measurements of barometric pressure or from measurements of cloud motion above the marine boundary layer. The shipboard measurements clearly show three distinct wind regimes: southerly winds from the Ecuador coast to $84^{\circ} \mathrm{W}$, South-East Trades between $84^{\circ} \mathrm{W}$ and $88^{\circ} \mathrm{W}$, and easterly winds in the area of the Galápagos Islands that vary spatially such that the air flows around islands. The transitions between these regimes on both the eastward and westward transit was distinct.

The ship winds were used to estimate wind stress curl in the two transition regions. Between $84^{\circ} \mathrm{W}$ and $83^{\circ} \mathrm{W}$, the wind stress curl was estimated at $-9.4 \times 10^{-7} \mathrm{~N} \mathrm{~m}^{-1}$, while between $88^{\circ} \mathrm{W}$ and $87^{\circ} \mathrm{W}$, the curl was $-8.8 \times 10^{-7} \mathrm{~N} \mathrm{~m}^{-1}$. As expected, these curls were about an order of magnitude greater than those from climatology (Fig. 1 in Kessler, 2006). If these sharp transition regions persist, they could contribute to the formation of cyclonic ocean circulation features between the Galápagos Islands and South America and perhaps explain the cyclonic trough observed by Kessler (2006).
Acknowledgements. The Chief Scientist for the cruise was Timothy Herbert of Brown University. Liz Caporelli, Woods Hole Oceanographic Institution, arranged for and provided ADCP data collected on the cruise. ADCP data were processed and quality controlled by Jules Hummon, University of Hawaii. 2009 hourly sea level data for La Libertad were provided by the Ecuador Navy. Tetyana Margolina and Thomas Rago assisted with data analysis and preparation of the manuscript. Support from NSF award DMS-1025535 is gratefully acknowledged. The comments of two anonymous reviewers and Eric Firing were helpful and considerably improved the manuscript.

\section{References}

Allauca, S.: Presencia de la corriente costanera Ecuatoriana, Acta Oceanográfica del Pacifico, 6, 10-17, 1990.

Chaigneau, A., Gizolme, A., and Grados, C.: Mesoscale eddies off Peru in altimeter records: Identification algorithms and eddy spatio-temporal patterns, Prog. Oceanogr., 79, 106-119, 2008.

Chavez, F.: The Legitimate El Niño Current, Tropical OceanAtmosphere Newsletter, 34, p. 1, 1986.

Church, J. A. and White, N. J.: A 20th century acceleration in global sea-level rise, Geophys. Res. Lett., 33, L01602, doi:10.1029005GL024826, 2006.

Collecte Localisation Satellites: SSALTO/DUACS User Handbook: (M) SLA and (M) ADT near real time and delayed time products, CLS-DOS-NT-06.034, Ramonville Saint-Agne, France, 2006.

Donohue, K. A., Firing, E., Rowe, G. D., Ishida, A., and Mitsudera, H.: Equatorial Pacific Subsurface Countercurrents: A ModelData Comparison in Stream Coordinates, J. Phys. Oceanogr., 32, 1252-1264, 2002.

Hayes, S. P.: Sea Level and Near Surface Temperature Variability at the Galapagos Islands, 1979-83, in: El Niño en las Islas Galápagos: El Evento de 1982-1983, Fundación Charles Darwin para los Islas Galápagos, Quito, Ecuador, 49-81, 1985.

Hayes, S. P., Mangum, L. J., Barber, R. T., Huyer, A., and Smith, R. L.: Hydrographic Variability West of the Galápagos Islands 
during the 1982-83 El Niño, Prog. Oceanogr., 17, 137-162, 1986.

Karnauskas, K. B., Murtududde, R., and Busalacchi, A. J.: Observing the Galápagos-EUC Interaction: Insights and Challenges, J. Phys. Oceanogr., 40, 2768-2777, 2010.

Knauss, J. A.: Further Measurements and Observations of the Cromwell Current, J. Marine Res., 14, 205-240, 1966.

Kessler, W. S.: The circulation of the eastern tropical Pacific: A review, Prog. Oceanogr., 69, 181-217, 2006.

Lucero, M. and Cornejo Rodriguez, M. P.: Evidencia de la corriente de Cromwell entre $92^{\circ} \mathrm{W}$ y $84^{\circ} \mathrm{W}$, observada en periodos normales y durante El Niño 82-83, Acta Oceanográfica del Pacifico, 6, 18-27, 1990.

Lucero, M.: Distribución de las corrientes alrededor de las Islas Galápagos, Acta Oceanográfica del Pacifico, 10, 21-27, 2000.

Lukas, R.: The Termination of the Equatorial Undercurrent in the Eastern Pacific, Prog. Oceanog., 16, 63-90, 1986.

Martinez, R., Zambrano, E., and Garcés, J.: Predicción del evento El Niño 97-98 en el mar Ecuatoriano usando métodos estadísticos, Acta Oceanográfica del Pacifico, 10, 1-8, 2000.

Martinez, R., Zambrano, E., Vera, L., Briones, K., and Zambrano, L.: Indice multívariado del El Niño en el Ecuador, Acta Oceanográfica del Pacifico, 11, 1-6, 2002.

Montes, I., Colas, F., Capet, X., and Schneider, W.: On the pathways of the equatorial subsurface currents in the eastern equatorial $\mathrm{Pa}-$ cific and their contributions to the Peru-Chile Undercurrent, J. Geophys. Res., 115, C09003, doi:10.1029JC005710, 2010.
Pak, H. and Zaneveld, J. R. V.: The Cromwell Current on the East Side of the Galapagos Islands, J. Geophys. Res., 78, 7845-7859, 1973.

Steger, J., Collins, C., and Chu, P.: Circulation in the Archipiélago de Colón (Galapagos Islands), November 1993, Deep-Sea Res. Pt. II, 45, 1093-1114, 1998.

Stevenson, M. R. and Taft, B. A.: New Evidence of the Equatorial Undercurrent East of the Galapagos Islands, J. Mar. Res., 29, 103-115, 1971.

Strub, P. T., Mesias, J. M., Montecino, V., Rutllant, J., and Salinas, S.: Chapter 10. Coastal Ocean Circuation off Western South America, in: The Sea, Vol. 11, edited by: Robinson, A. R. and Brink, K., John Wiley, Hoboken, N.J., 273-314, 1998.

Talley, L. D., Pickard, G. L., Emery, W. J., and Swift, J. H.: Descriptive Physical Oceanography: An Introduction, Academic Press, London, 555 pp., 2011.

Tsuchiya, M. and Talley, L. D.: A Pacific hydrographic section at $88^{\circ} \mathrm{W}$ : Water-property distribution, J. Geophys. Res. 103, 12899-12918, 1998.

Wyrtki, K.: Monitoring the Strength of Equatorial Currents from XBT Sections and Sea Level, J. Geophys. Res., 83, 1935-1940, 1978.

Zambrano, Q., Martinez, R., and Garcés-Vargas, J.: Variabilidad oceanografica en Ecuador asociada con el evento ENSO 199798, Acta Oceanográfica del Pacifico, 10, 9-20, 2000. 